\title{
Annual variation of fluoride level in drinking water in certain regions of the Republic of North Macedonia
}

\author{
Lirije Hamiti Alil $^{1 *}$, Rejhan Muhamed Djumkar ${ }^{1}$, Mihail Kochubovski ${ }^{1}$, \\ Tanja Petreska Ivanovska ${ }^{2}$, Zoran Zhivikj ${ }^{2}$, Olga Gigopulu ${ }^{3}$, Lidija Petrushevska-Tozi ${ }^{2}$ \\ ${ }^{1}$ Institute of Public Health, 50 Division 6, 1000 Skopje, Republic of North Macedonia \\ ${ }^{2}$ Institute of Applied Biochemistry, Faculty of Pharmacy, Ss. Cyril and Methodious University, \\ Mother Theresa 47, 1000 Skopje, Republic of North Macedonia \\ ${ }^{3}$ Faculty of Pharmacy, Ss. Cyril and Methodious University, \\ Mother Theresa 47, 1000 Skopje, Republic of North Macedonia
}

Received: May 2019; Accepted: June 2019

\begin{abstract}
Fluoride levels in drinking water varies in a wide range, which mainly depends on the geological and physical-chemical characteristics of the soil, the porosity of the mineral rocks in the region, the temperature, and the depth of the aquifer. When present at appropriate levels is recommended for prevention of dental caries, but high levels may provoke fluorosis. Hence, determination of fluoride concentration considering the balance between benefits and risks to health is an important parameter for the water quality assessment.

In this study, the annual variation of fluorides in drinking water comprising different regions of the Republic of North Macedonia was analyzed. The total dissolved fluoride was determined potentiometrically using a fluoride combined ion-selective electrode (ISE) and a $\mathrm{pH}$ meter with an enlarged millivolt $(\mathrm{mV})$ scale.

WHO recommended fluoride in drinking water to range from 0.5 to $1.5 \mathrm{mg} / \mathrm{L}$ in order good health of teeth to be provided. The results of this study indicated that analyzed 104 samples of water contained fluorides in lower quantities compared to upper safety limit established by our national legislation and Guidelines for Drinking Water Quality of the WHO. During the summer period, in the majority of the samples fluoride levels were further reduced compared to other seasons, which may due to a lower amount of rain. With regard to this, the obtained data for relatively low fluoride levels in water may serve to dentists both in clinical practice and public dental health, implying current information necessary for advising on fluoride supplementation to people.
\end{abstract}

Keywords: Fluoride, drinking water, fluoride analysis, potentiometric method

\section{Introduction}

Water is the substantial compound required by an individual for survival. With the daily consumption of water people are exposed to various compounds present in water which can be either beneficial or harmful. Hence, various parameters of drinking water are monitored on regular basis to ensure consumption of water with permissible limits of different compounds that may be present (Ram et al., 2019).

Fluorine in water forms stable complexes with $\mathrm{Al}^{3+}$, $\mathrm{Be}^{2+}$ and $\mathrm{Fe}^{3+}$ ions, and with boron it forms mixed fluoride-hydroxy complexes. As fluoride ion has the same electricity and almost the same radius as hydroxide ion, these ions can mutually change in mineral structures. The

\footnotetext{
*lirije_h@yahoo.com
} 
fluorine is very toxic chemical element; it is very rare in its elemental form. It is a common element that is widely distributed in Earth's crust and exists in the form of fluorides in a number of minerals, such as fluorspar, cryolite and fluorapatite. The inorganic compounds are divided into soluble ( $\left.\mathrm{NaF}, \mathrm{HF}, \mathrm{H}_{2} \mathrm{SF}_{4}, \mathrm{Na}_{2} \mathrm{PO}_{3} \mathrm{~F}\right)$, less soluble $\left(\mathrm{CaF}_{2}\right.$, phosphates, cryolites), and inert $\left(\mathrm{KF}_{4}\right.$ and others). One recent research underlined the widespread distribution of fluorides in nature, most often in the form of fluorescents $\mathrm{CaF}_{2}$, fluoro-apatite $\mathrm{Ca}_{10}\left(\mathrm{PO}_{4}\right){ }_{6} \mathrm{~F}_{2}$, and cryolite $\mathrm{Na}_{3} \mathrm{AlF}_{6}$ (Rajković and Novaković, 2007).

The fluoride ion is the ionic form of the element fluorine, which is found in abundance in nature, primarily in water and soil. Many natural products, such as tea, may contain significant quantities of fluorides (Rajković and Novaković, 2007). Traces of fluorides can be found in many waters, with higher levels often associated with groundwater's (WHO, 2017). In fact, drinking water is the major source of naturally occurring fluoride intake and its concentration in natural groundwater typically ranges between 0.1 and $10 \mathrm{mg} / \mathrm{L}$ (WHO, 2008). According to Dar et al. (2011), fluoride ion

$\left(F^{-}\right)$occurs in almost all waters from trace to high levels and it has been shown to cause significant effects in humans through drinking water (WHO, 2006).

Optimal fluoride levels in drinking water have been considered beneficial to prevent dental carries (Maliyekkal et al., 2008; Qin et al., 2009), but excessive exposure to fluoride in drinking water can give rise to a number of adverse effects including dental and skeletal fluorosis, impaired development of intelligence in children as well as decreased birth rate (Aldrees and Al-Manea, 2010; Armienta and Segovia, 2008; Arveti et al., 2011; Dunne and Verrel, 2011; Wanke et al., 2017; WHO, 2006). Hence, WHO has set a limit value of $1.5 \mathrm{mg} / \mathrm{L}$ for fluoride in drinking water (Rafique et al., 2008; WHO, 2004). Our national legislation complied with the maximal limit suggested by WHO and European Union for fluoride levels in drinking water (Rulebook on Requirements for Safety and Quality of Drinking Water in the Republic of the North Macedonia, Official Gazette of Republic of Macedonia № 183, 2018). When its intake does not exceed optimal levels, fluoride is involved in stimulating normal mineralization of bones, formation of dental enamel and maintenance of fertility (Dey and Giri, 2016). With regard to this, in 1999 , it was declared that the fluoridation of drinking water is considered to be one of the ten greatest achievements in public health in the 20th century. According to the WHO water fluoridation is the safest, most economical and most effective means of preventing and controlling tooth decay (Petersen, 2003). In their latest view on this subject, fluoridation of water was also supported, arguing that the practice is both safe and equitable, since all population groups' benefit from it (WHO, 2017). Comprising the WHO recommendations, the populations that are the most underprivileged and the hardest to reach with conventional preventive services are also the populations most likely to benefit from fluoridation. In this sense, fluoridation can be seen as a public health measure.

Since water is the main source of ingested fluoride for human, knowledge of the fluoride levels in drinking water and the establishment of safety levels is an important issue. For an individual, fluoride exposure $(\mathrm{mg} / \mathrm{kg} /$ day) via drinking water is determined by the fluoride level in the water and the daily water consumption (Amanlou et al., 2010). Water consumption increases with temperature, humidity, exercise and state of health, and it is modified by other factors including diet. In conjunction with this and as a result of a narrow margin between the desired and harmful fluoride levels in drinking water (Jha et al., 2011), the objective of the present study was to provide data for annual variations by using an accurate, simple, rapid and cost-effective analytical method.

\section{Materials and Methods}

\section{Sampling procedure}

The total number of tested drinking water samples was 104 , taken from different cities and different districts respecting the one city. The samples were taken in different months starting from January to December during 2017. The test samples were submitted in the original and undamaged packaging of the Institute for Public Health in Skopje. Water samples were placed in plastic containers and stored in a refrigerator (not frozen) before reaching the laboratory (Rulebook on Requirements for Safety and Quality of Drinking Water in the Republic of the North Macedonia, Official Gazette of Republic of Macedonia № 183, 2018).

\section{Determination of fluoride (ISE potentiometric titration)}

The total dissolved fluoride was determined potentiometrically using a fluoride combined ion-selective electrode (ISE) (Thermo Fisher Scientific, USA) and a pH meter with an enlarged millivolt $(\mathrm{mV})$ scale (Thermo Fisher Scientific, USA). An ion-selective electrode is the most cost-effective, efficient and reliable analytical method for determination of the fluoride level in various samples. By means of this method it is possible to measure the total amount of free and complex-bound fluoride dissolved in water. The method can be used for water containing at least $20 \mu \mathrm{g} / \mathrm{L}$ fluorides (Amanlou et al., 2010). In addition, the method used to measure total hydrogen fluoride ions in drinking water was in accordance to the method provided by American Society for Testing and Materials (ASTM D 1179) (Eaton et al., 1995). In brief, the standards and samples were mixed in a ratio of 10:1 with a TISAB solution, a German adjusting buffer for total ionic strength (Sigma Aldrich, USA). TISAB reagent contains a gelatinous agent that breaks 
Table 1. An overview of sampling scheme in accordance with the period of sampling (months) and area (cities).

\begin{tabular}{|c|c|c|c|c|c|c|c|c|c|}
\hline City & Kumanovo & Veles & Radovish & Kratovo & Shtip & Probishtip & Delchevo & Ohrid & Skopje \\
\hline Month & \multicolumn{9}{|c|}{ Number of samples per month } \\
\hline January & & & & 2 & & & & & \\
\hline February & & 2 & 3 & & & & & & \\
\hline March & & & & 2 & 2 & & & & \\
\hline April & 6 & & & & & & 4 & & \\
\hline May & & & & & & 3 & & & \\
\hline June & & 2 & & & & & & 5 & 16 \\
\hline July & & & 3 & 2 & & & & & \\
\hline August & & & & & 2 & & & & \\
\hline $\begin{array}{l}\text { September } \\
\text { October }\end{array}$ & 6 & 2 & & 2 & & & 4 & & 16 \\
\hline November & & & & & & 3 & & & \\
\hline December & 6 & & & 2 & 2 & & & 5 & \\
\hline Total & & & & & 104 & & & & \\
\hline
\end{tabular}

down the metal-fluoride complexes. The working standards were prepared using sodium fluoride (Fluka, Switzerland). For calibration of the instrument and construction of standard curve, serial dilutions of the solution of sodium fluoride with the initial concentration of $100 \mathrm{mg} / \mathrm{L} \mathrm{F}^{-}$, were prepared. Afterwards, to a specified volume of standard solution were added $10 \mathrm{~mL}$ of distilled water, and $1 \mathrm{~mL}$ TISAB, while the test samples were mixed with TISAB only. The $\mathrm{pH}$ of the working standards as well as the samples ranged from $\mathrm{pH}$ 5.0-5.5. Both standard solutions and test samples were placed in polyethylene containers. Then the content was mixed on a magnetic stirrer at slow speed, shortly. The electrode over the magnet was submerged and allowed the value on the display of the instrument to be stabilized. The read value was expressed as $\mathrm{mg} / \mathrm{L}$ fluorides. The value obtained was corrected by a correction factor of 1.1 which was obtained from the ratio of the volumes of the standard solution and the sample (Equation 1).

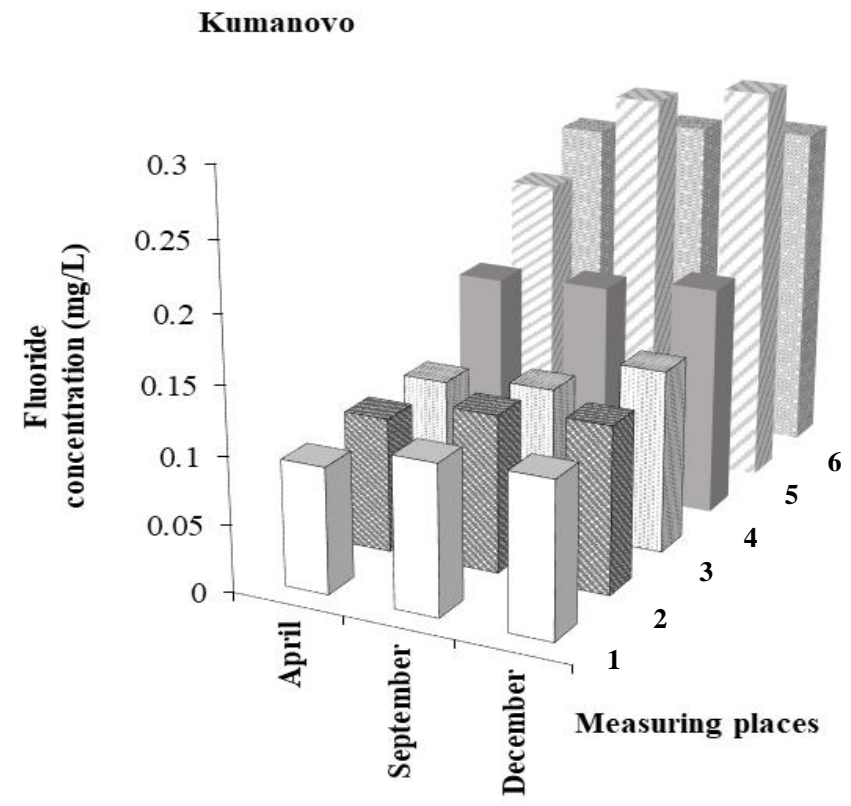

Fig. 1. Diagram of annual variations of fluoride concentration in drinking waters in Kumanovo region; drinking waters taken from six measuring places were analyzed.

Макед. фарм. билт., 65 (1) 83 - 93 (2019) 


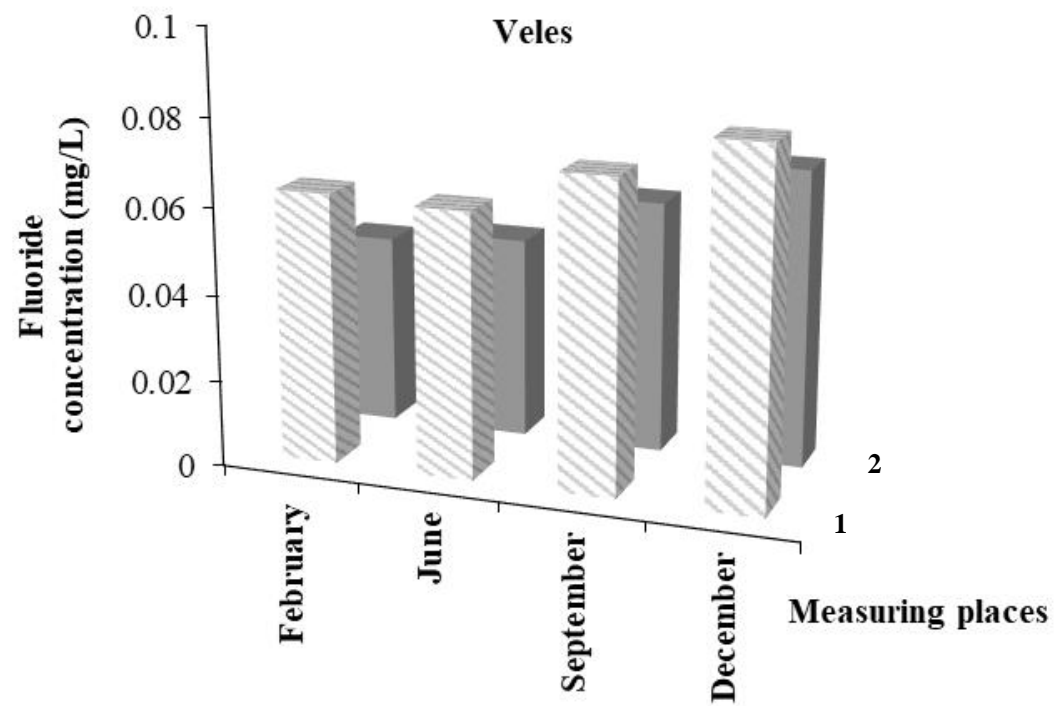

Fig. 2. Diagram of annual variations of fluoride concentration in drinking waters in Veles region; drinking waters taken from two measuring places were analyzed.

\section{Results and discussion}

Measuring of the fluoride level in drinking water is important to examine the risk associated with low or high fluoride concentration which may impact health. This paper presents the results of the analyses carried out to determine the amount of fluoride by means of an ion selective method in drinking water samples taken from different regions in our country. The obtained data are useful to identify the areas where there was a likely probability of exceeding the critical threshold of $1.5 \mathrm{mg}$ fluorides per liter in drinking water or its deficiency. The results of the specified values of the fluorides for different cities respecting the period of the measuring are shown in separate diagrams.

The bars of the diagram respective to six different measuring places covering the waters of the city of Kumanovo (Fig. 1) showed a slight increase in fluoride levels during the year, in different seasons. In the autumn and winter, we observed increased humidity that is rains and snow, and then there is a slight increase in fluoride levels. Samples taken from measuring points 5 and 6 were observed to contain significantly higher fluoride level compared to other tested samples comprising Kumanovo region.

The fluoride levels in the drinking waters of Veles region were observed to be almost equal in February and June, while an increase can be seen in September and December (Fig. 2). This is probably due to the season when it rains.

From the diagram covering the waters of the city of Radovish (Fig. 3), a slight increase in the value of fluorides in water can be seen in July which is not usually associated with weather change, but may be related to the characteristics of the soil.

An increase of fluoride content in drinking waters respecting the region of Kratovo (Fig. 4) has been observed in September and December mostly due to the rainy season, while the measurement carried out in January, March and July showed lower fluoride levels. Significant difference of the fluoride levels in drinking water was observed between samples taken from different measuring point. As far as the sample taken from the measuring place 1 represents a mineral water, it is expected to be rich with many minerals and among them fluorides.

The diagram representing the levels of fluorides in drinking waters covering the region of Shtip (Fig. 5), indicated continuous increase during 2017. The highest fluoride level was measured in December. In view of the difference of fluoride levels found between samples taken from different measuring places, one can conclude that the water from measuring place 1 had significantly lower level of fluorides. This finding indicated that the water from measuring place 2 probably passes through soil richer in minerals.

Fig. 6 showed there was a very small difference in the concentration of fluorides determined in drinking waters between two measuring, in May and November for the region of Probishtip town. Insignificantly increased values found in November compared to May are probably related to rainy and snowing weather.

In the town of Delchevo, for drinking water samples taken from all four measuring places, increase of fluoride level in September has been observed compared to fluoride level found in respective drinking waters in April 


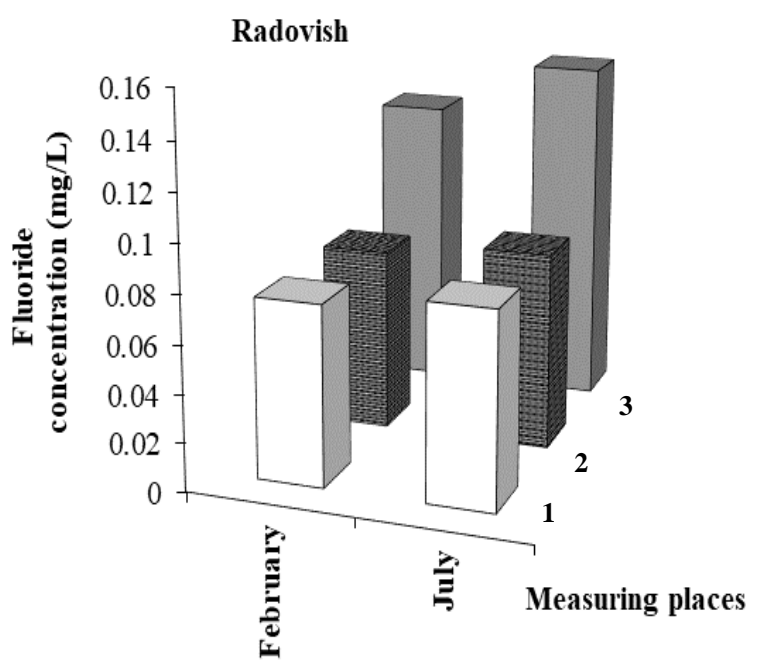

Fig. 3. Diagram of annual variations of fluoride concentration in drinking waters in Radovish region; drinking waters taken from three measuring places were analyzed.

(Fig. 7). This finding is in accordance with the assumption that the rainy weather contributes to increase of fluoride levels in drinking water.

Drinking waters covering the region of Ohrid (Fig. 8) showed slight increase of the fluoride levels in December compared to measured values for respective samples in June. The diagram also showed that the water taken from measuring place 5 is richer with fluorides compared to other four tested samples.
Measurements performed in June and September showed insignificant difference in fluoride level in drinking waters between respective samples comprising all sixteen measuring places in Skopje region (Fig. 9). Compared to respective fluoride levels determined in June, a slight increase was found in September. Hence, it can be concluded that the variations of fluoride levels in drinking waters covering the region of Skopje were insignificant in 2017.

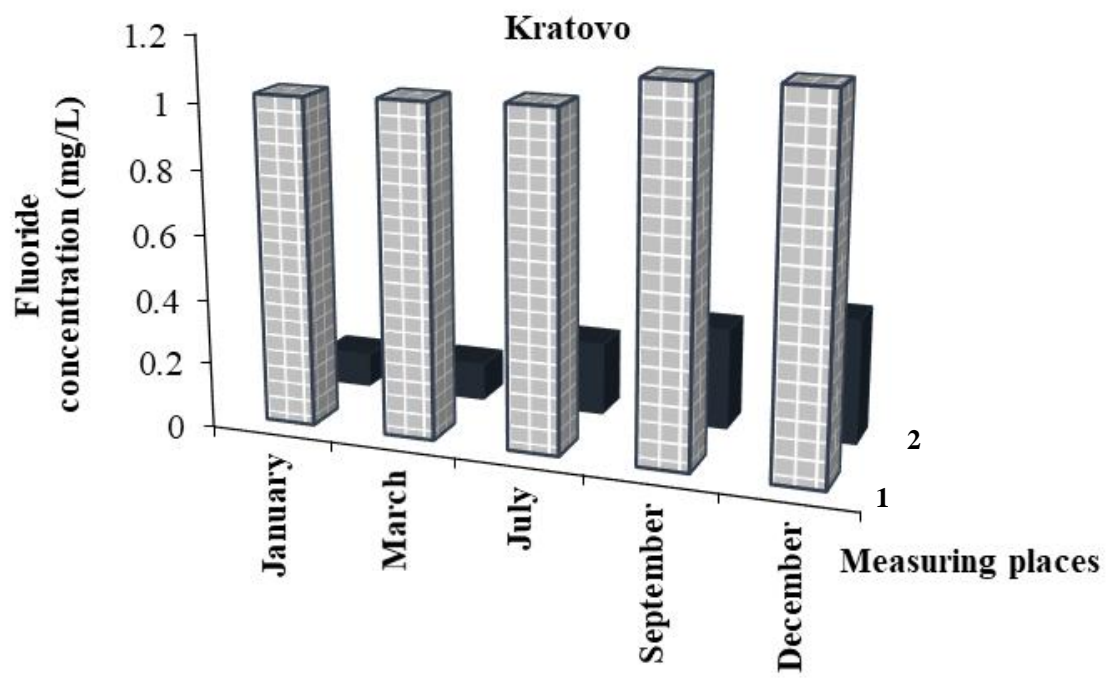

Fig. 4. Diagram of annual variations of fluoride concentration in drinking waters in Kratovo region; drinking waters taken from two measuring places were analyzed. 


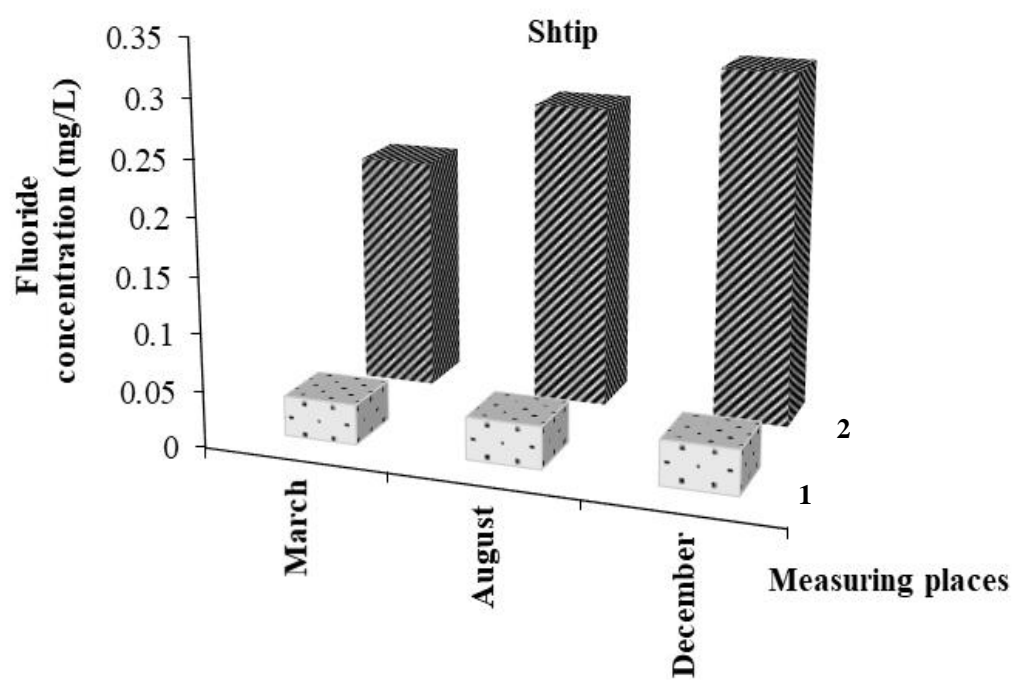

Fig. 5. Diagram of annual variations of fluoride concentration in drinking waters in Shtip region; drinking waters taken from two measuring places were analyzed.

The origin of elevated fluoride concentration in drinking water primary due to the soil characteristics, i.e. enriched with minerals and, to climate and hydrogeological factors (Tokalioğlu et al., 2001), while establishing national standards for drinking water it is essential to put in mind the possible health risks associated with excessive fluoride exposure. The annual pattern of fluoride levels measured in drinking water including certain regions in our country has been shown that there is no concern of exposure to high levels of fluorides as far as all examined samples contained fluorides less than maximum allowed level according to our national Rulebook on requirements for safety and quality of drinking water (Rulebook on Requirements for Safety and Quality of Drinking Water in the Republic of the North Macedonia, Official Gazette of Republic of Macedonia № 183, 2018). Based on these results fluoride surplus was not found, and as a consequence respecting the involved regions, there is no area where exists a probability of exceeding the critical threshold of $1.5 \mathrm{mg} / \mathrm{L}$ fluoride in drinking water. In fact, the analyzed samples contained relatively low fluoride level questionable it is satisfying to

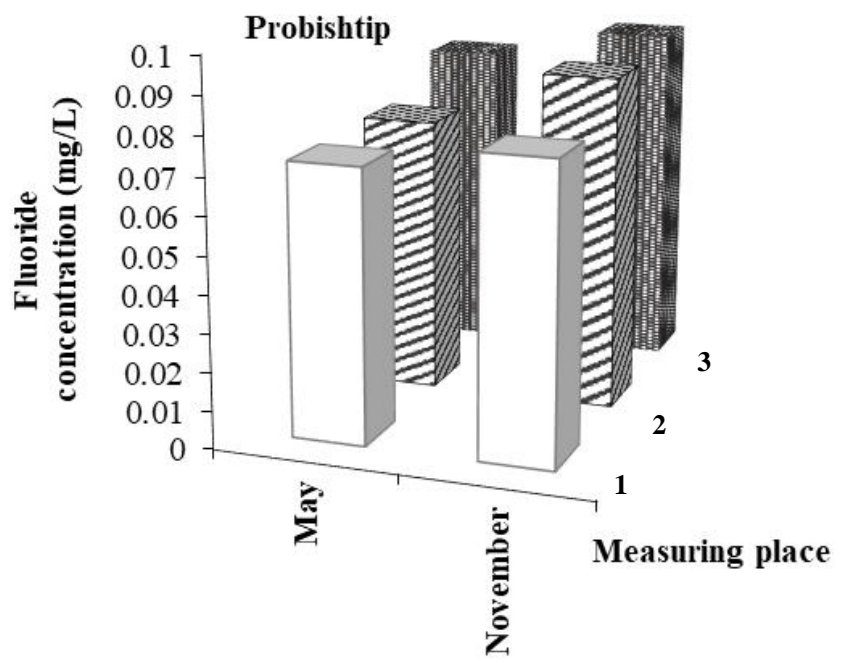

Fig. 6. Diagram of annual variations of fluoride concentration in drinking waters in Probishtip region; drinking waters taken from three measuring places were analyzed. 


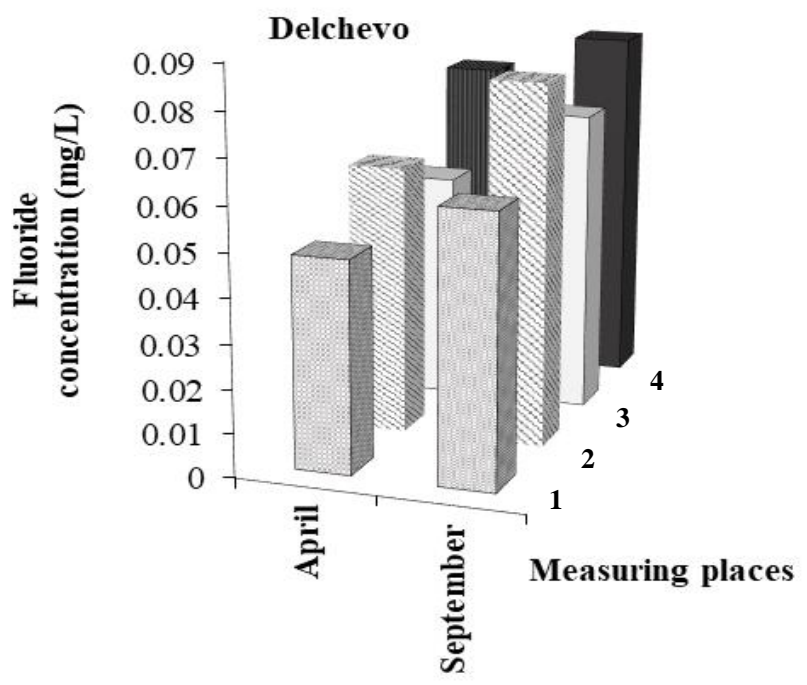

Fig. 7. Diagram of annual variations of fluoride concentration in drinking waters in Delchevo region; drinking waters taken from four measuring places were analyzed.

avoid the risk of teeth damage related to fluoride deficiency or even absence. In the light of the results obtained, the fluoride levels of the drinking waters in our country are rather low regarding the minimum recommended values for fluoride within the drinking water to reduce tooth decay, have been deemed by the WHO to be $0.5 \mathrm{mg} / \mathrm{L}$ (WHO, 2004). In most drinking waters in which the determination of fluoride was performed in the Republic of North Macedonia, the fluoride concentrations were observed to be below 0.5 $\mathrm{mg} / \mathrm{L}$. The only exemption was the sample taken from measuring point 1 in Kratovo (Fig. 4) contained fluorides above $1 \mathrm{mg} / \mathrm{L}$ implying the probability this water to pass through a soil or a rock layer which is significantly richer in fluoride than the other regions. Two water samples taken from measuring points 5 and 6 in Kumanovo region (Fig. 1) and one sample taken from measuring point 2 in Shtip (Fig. 5) showed fluoride level above $0.2 \mathrm{mg} / \mathrm{L}$ which was higher compared to the majority of the examined samples. Since low levels of fluoride, i.e. less than $0.1 \mathrm{mg} / \mathrm{L}$ could increase the possibility of dental caries, it is important to underline that in water samples

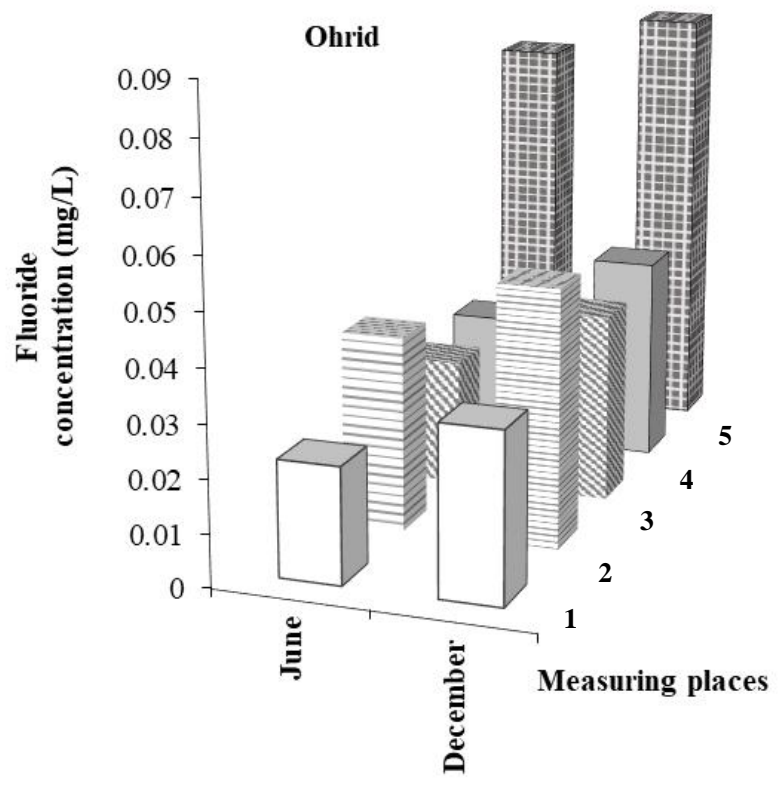

Fig. 8. Diagram of annual variations of fluoride concentration in drinking waters in Ohrid region; drinking waters taken from five measuring places were analyzed.

Макед. фарм. билт., 65 (1) 83 - 93 (2019) 


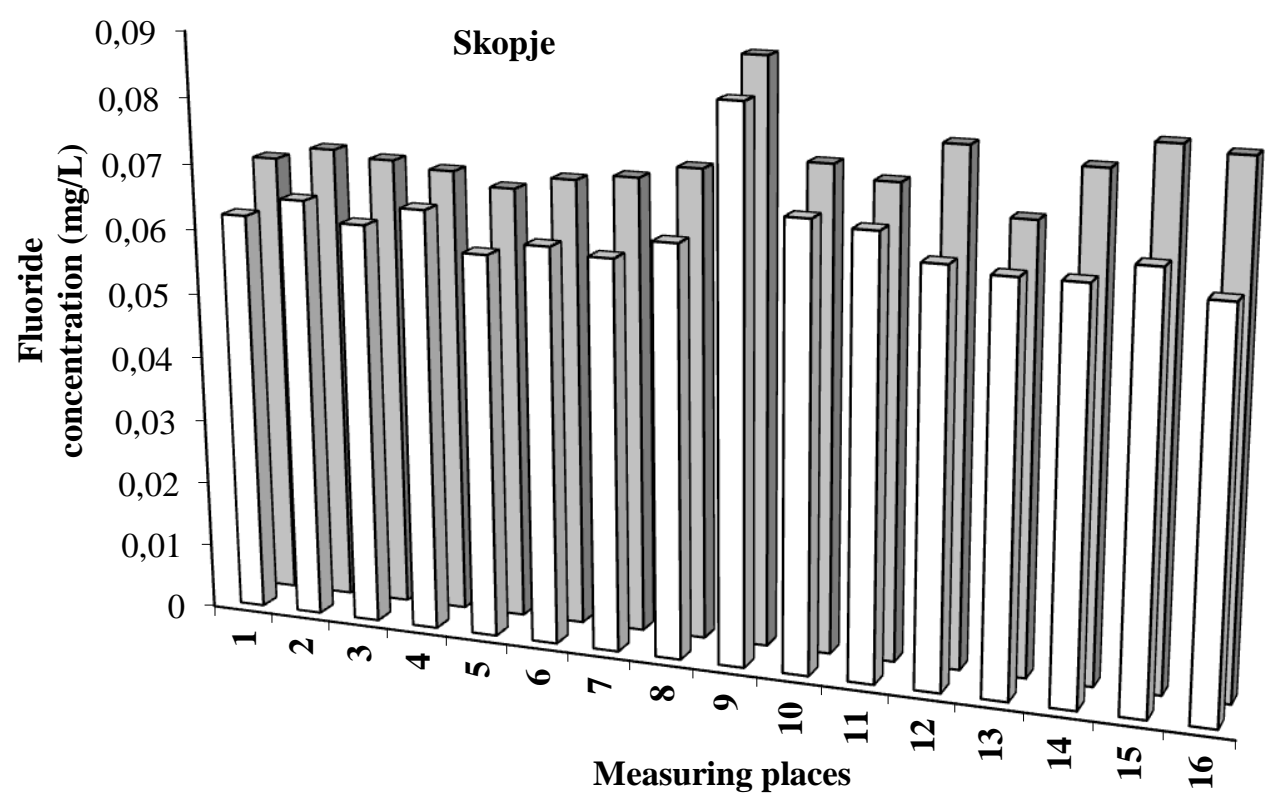

Fig. 9. Diagram of annual variations of fluoride concentration in drinking waters in region of Skopje; drinking waters taken from sixteen measuring places were analyzed. White and gray bars represent the concentration of fluoride measured in different samples in September and December, respectively.

taken from at least one measuring point in all studied regions excluding Kratovo, fluoride concentration was found to vary in a range of 0.022 to $0.099 \mathrm{mg} / \mathrm{L}$. In general, low fluoride level in drinking water observed among examined samples in this study may be explained by the chemical structures and insufficient dissolving properties of minerals in the waters passing through soil and rock layers rich in minerals (Tokalioğlu et al., 2001).

The effects of fluoride are best predicted by the dose (i.e. $\mathrm{mg}$ fluoride per $\mathrm{kg}$ of body weight per day), the duration of exposure and other factors such as age and diet. Factors such as intake of water by the population in a designated environment, as well as intakes from sources such as food, air, and dental products, all contribute to the total consumption and ingestion of fluoride in a given environment. From the other point of view, poor nutritional status may be an important contributory factor to dental caries (Amanlou et al., 2010). However, drinking water is typically the largest single contributor to daily fluoride intake (Murray, 1986) and for a given individual, fluoride exposure via drinking water is determined by the fluoride level in the water and the daily water consumption (litres per day). Consequently, most often the effects of fluoride on teeth and bone are correlated rather with the concentration of fluoride in the drinking water (mg/L fluoride) consumed than total fluoride exposure. Fluorine ion in organism has its optimal dose, which depends of person's age, weight and health. In the first year of life, the optimal dosage is $0.045 \mathrm{mg} / \mathrm{kg}$ of body weight, while for adults is $0.020-0.025 \mathrm{mg} / \mathrm{kg}$ (Rajković and Novaković, 2007).

A number of organizations around the world have examined the effects of fluoride on human health. The reviews of the National Research Council (NRC, 1993), which are frequently cited in the literature (Levy and Corbeil, 2007), report no toxic health effects associated with fluoride concentrations recommended to prevent tooth decay. According to the percentage of fluoride ion representation in the Earth's crust $(0.08 \%)$ (Peckham and Awofeso, 2014), it is placed on the $13^{\text {th }}$ place in nature, with the difference that is most present in mineral rocks of volcanic origin. Natural waters contain less than $0.1 \mathrm{mg} / \mathrm{L}$ fluoride ions, while mineral waters contain 0.16 to 6.45 $\mathrm{mg} / \mathrm{L}$, on average. The largest number of the world's population consumes drinking water with a fluoride content below $1 \mathrm{mg} / \mathrm{L}(1 \mathrm{ppm})$ of water. There are a lot of regions in the world with drinking waters that are even poorer in fluorides than our country, hence the fluoridation of drinking water has been recommended by the WHO, among other important worldwide entities within the field of healthcare. In this respect, water fluoridation was highlighted as an effective, safe and cheap intervention that should be implemented and maintained wherever it is possible since 1986 (Murray, 1986). However, the review of Peckham and Awofeso (2014) has challenged the enthusiasm with which fluoride was introduced as a public health measure and asked for a more rational analysis of its benefits and costs as a caries 
prevention technology, arguing that the modest benefits of ingested fluoride are thoroughly counterbalanced by its potential diverse adverse effects on human health. Considering all the arguments for anti- and profluoridation, the best way for dental caries prevention is to take into account overall assessment of past fluoride exposure and to people, especially children and adolescents, who are not exposed to community water fluoridation, to include fluoride supplements or use of over-the-counter rinses and gels.

\section{Conclusion}

According to the obtained results for fluoride levels in drinking waters covering certain regions of the Republic of North Macedonia during one-year period from January to December 2017, it can be concluded that lower fluoride level related to sunny weather without rain, is typical during the summer period. Usually, in November and December after rainfall, there is an increase in fluoride levels in drinking water. In addition, the presence of fluorides in the water varies in a wide range, which mainly depends on the geological and physical-chemical characteristics of the soil, the porosity of the mineral rocks in the region, the temperature and the depth of the aquifer.

From a health point of view, if there is a greater amount of fluorides in drinking water than $6 \mathrm{mg} / \mathrm{L}$, it is associated with risk bones fluorosis to be developed. A quantity of above $2 \mathrm{mg}$ fluorides per liter leads to fluorosis of teeth (a change in dental plaque). On contrast, good health of teeth cannot be provided if fluorides are absent or present in very low levels in drinking water. This problem seems to be a global health concern and hence the fluoridation of drinking water has been recommended by the WHO. Comprising the situation in our country, the majority of drinking waters are insuficient in fluorides. However, fluoride was found in all drinking waters and regarding the health safety imposes no need of water fluoridation. Nevertheless, intervention measures for additional fluoride supplementation may be needed at individual level.

\section{References}

Aldrees, A.M., Al-Manea, S.M., 2010. Fluoride content of bottled drinking waters available in Riyadh. Saudi Dent. J. 22(4), 189-193. Available at:

https://doi.org/10.1016/j.sdentj.2010.07.003.

Amanlou, M., Hosseinpour, M., Azizian, H., Khoshayand, M.R., Navabpoor, M., Souri, E., 2010. Determination of fluoride in the bottled drinking waters in Iran. Iran. J. Pharm. Res. 9(1), 37-42. Available at: https://doi.org/10.22037/IJPR.2010.833

Armienta, M.A., Segovia, N., 2008. Arsenic and Fluoride in the
Groundwater of Mexico. Environ. Geochem. Health, 30(4), 345-353. Available at: https://doi.org/10.1007/s10653-0089167-8.

Arveti, N., Sarma, M.R., Aitkenhead-Peterson, J.A., Sunil, K., 2011. Fluoride incidence in groundwater: a case study from Talupula, Andhra Pradesh, India. Environ. Monit. Assess. 172(1-4), 427-443. Available at: https://doi.org/10.1007/s10661-010-1345-3.

Dar, M.A., Sankar, K., Dar, I.A., 2011. Fluorine contamination in groundwater: a major challenge. Environ. Monit. Assess. 173 955-968. Available at: https://doi.org/10.1007/s10661010-1437-0.

Dey, S., Giri, B., 2016. Fluoride fact on human health and health problems: A review. Med. Clin. Rev. 2(1:11), 1-6. Available at: https://doi.org/10.21767/2471-299X.100011.

Dunne, K., Verrell, P., 2011. Acute effect of exposure to sodium fluoride on the red compost earthworm Eisenia fetida: Lethality and avoidance behavior. Fluoride 44, 210-214.

Eaton, A.D., Clesceri, L.S., Greenberg, A.E., 1995. Standard Methods for the Examination of Water and Wastewater, 19th ed. Amer Public Health Assn, Washington DC.

Jha, S.K., Nayak, A.K., Sharma, Y.K., 2011. Site specific toxicological risk from fluoride exposure through ingestion of vegetables and cereal crops in Unnao district, Uttar Pradesh, India. Ecotoxicol. Environ. Saf. 74, 940-946. Available at: https://doi.org/10.1016/j.ecoenv.2011.01.002.

Levy, M., Corbeil, F., 2007. Water fluoridation: An analysis of the health benefits and risks. Scientific advisory of Institute for public health of Quebec, Legal Deposit 4RD Quarter, Library and Archives Canada, Government of Quebec, pp. 11-17.

Maliyekkal, S.M., Shukla, S., Philip, L., Nambi, I.M., 2008. Enhanced fluoride removal from drinking water by magnesia-amended activated alumina granules. Chem. Eng. J. 140, 183-192. Available at: https://doi.org/doi.org/10.1016/j.cej.2007.09.049.

Murray, J., 1986. Appropriate Use of Fluorides for Human Health, ed. World Health Organization, International Dental Federation \& W.K. Kellogg Foundation, Macmillan/Ceuterick, Belgium, part 1, pp. 83.

National Research Council, 1993. Health Effects of Ingested Fluoride, ed. The National Academies Press National Academy Press, Washington DC. Available at: https://doi.org/doi.org/10.17226/2204.

Peckham, S., Awofeso, N., 2014. Water fluoridation: A critical review of the physiological effects of ingested fluoride as a public health intervention. Sci. World. J. 293019. Available at: https://doi.org/10.1155/2014/293019.

Petersen, P.E., 2003. The World Oral Health Report, Continuous improvement of oral health in the 21 st century - the approach of the WHO Global Oral Health Programme. World Health Organization, Geneva, Switzerland.

Qin, X., Wang, S., Yu, M., Zhang, L., Li, X., Zuo, Z., Zhang, X., Wang, L., 2009. Child skeletal fluorosis from indoor burning of coal in Southwestern China. J. Environ. Public Health 1-7. Available at: https://doi.org//10.1155/2009/969764.

Rafique, T., Naseem, S., Bhanger, M.I., Usmani, T.H., 2008. Fluoride ion contamination in ground water of Mithi Subdistrict, the Thar Desert, Pakistan. Environ. Geol. 56, 317326. Available at: https://doi.org/10.1007/s00254-0071167-y. 
Rajkovic, M.B., Novakovic, I.D., 2007. Determination of fluoride content in drinking water and tea infusions using fluoride ion selective electrode. J. Agric. Sci. 52(2), 155168. Available at: https://doi.org/10.2298/JAS0702155R.

Ram, S.M., Thakkar, V.P., Machale, P., 2019. Determination of fluoride level in drinking water from water samples in Navi Mumbai, Maharashtra. J. Indian Assoc. Public Health Dent. 15, 395-398. Available at: https://doi.org/10.4103/jiaphd.jiaphd_95_17.

Rulebook on Requirements for Safety and Quality of Drinking Water in the Republic of the North Macedonia, Official Gazette of Republic of Macedonia № 183, 2018. Available at: http://www.slvesnik.com.mk/Issues/286e4acf37c84e09a6f 840347dc789a2.pdf. Last accessed: April 12, 2019.

Tokalioğlu, Ş., Şahĭn, U., Kartal, Ş., 2001. Determination of fluoride and some metal ion levels in the drinking waters in Kayseri province. Turk. J. Chem. 25, 113-121.
Wanke, H., Ueland, J.S., Hipondoka, M.H.T., 2017. Spatial analysis of fluoride concentrations in drinking water and population at risk in Namibia. Water SA 43(3), 413-422.

World Health Organization, 2017. Guidelines for Drinking Water Quality. Available at: https://www.who.int/water_sanitation_health/publications/ drinking-water-quality-guidelines-4-including-1 staddendum/en/. Last accessed: April 15, 2019.

World Health Organization, 2008. Guidelines for Drinking Water Quality. World Health Organization, Geneva. pp. 668 .

World Health Organization, 2006. Fluoride in Drinking-water. Background document for development of WHO Guidelines for Drinking-water Quality. World Health Organization, Geneva. pp. 17.

World Health Organization, 2004. Guidelines for Drinkingwater Quality, 2nd ed. Vol. 1. World Health Organization, Geneva. pp. 375-377.

\title{
Годишни промени на флуоридите во водите за пиење од определени региони во Република Северна Македонија
}

\author{
Лирије Хамити Алил ${ }^{1 *}$, Рејхан Мухамед Џумкар ${ }^{1}$, Михаил Кочубовски ${ }^{1}$, \\ Тања Петреска Ивановска ${ }^{2}$, Зоран Живиќ ${ }^{2}$, Олга Гигопулу ${ }^{3}$, \\ Лидија Петрушевска-Този ${ }^{2}$ \\ ${ }^{1}$ Институт за јавно здравје, 50 Дивизија 6, 1000 Скопје, \\ Република Северна Македонија \\ ${ }^{2}$ Институт за применета биохемија, Фармацевтски факултет, \\ Универзитет “Св. Кирил и Методиј”, Мајка Тереза 47, 1000 Скопје, \\ Република Северна Македонија \\ ${ }^{3}$ Фармаиевтски факултет, Универзитет “Св. Кирил и Методиј”, Мајка Тереза 47, \\ 1000 Скопје, Република Северна Македонија
}

Клучни зборови: Флуориди, вода за пиење, анализа на флуориди, потенциометриски метод

Застапеноста на флуоридите во водата за пиење варира во широк интервал, првенствено во зависност од геолошките и физичко-хемиските карактеристики на почвата, порозноста на минералните карпи во областа, температурата и длабочината на водата. Флуоридите присутни во водата за пиење имаат превентивното дејство од развој на дентален кариес, но во зголемени концентрации можат да предизвикаат флуороза. Затоа, земајќи ја во предвид рамнотежата помеѓу здравствените придобивки и ризици, определувањето на концентрацијата на флуориди претставува важен фактор за проценка на квалитетот на водата.

Во ова истражување беа следени годишните промени во концентрацијата на флуориди во водите за пиење во определени региони во Република Северна Македонија. За определување на вкупните растворени флуориди во водата беше применет потенциометриски метод со флуорид-комбинирана јон-селективна електрода и рН метар со миливолтна скала. 
СЗО препорачува концентрација на флуоридите во водата за пиење од 0.5 до $1.5 \mathrm{mg} / \mathrm{L}$ за да се одржи здравјето на забите. Резултатите од ова истражување што опфаќа анализа на 104 примероци покажуваат дека нивното ниво е пониско од максималната препорачана вредност за флуориди во водата за пиење согласно националната регулатива и водичите за квалитет на водата за пиење издадени од СЗО. За време на летниот период, во најголем број на примероци беше забележано понатамошно опаѓање на нивото на флуориди споредбено со останатите годишни времиња, што може да биде резултат на слабите врнежи. Сознанијата за релативно ниското ниво на флуориди во водата за пиење можат да послужат во клиничката стоматолошка практика, како и во јавното дентално здравје при советување на луѓето за потреба од примена на флуоридни препарати. 
